\title{
Segetal complex - pioneer stages of syntrophic communities in the Meshchovskiy Opole of the non-Chernozem Zone of Russia
}

\author{
Valeriy A. Burlutskiy ${ }^{1 *}$, Vladimir N. Mazurov ${ }^{1}$, Alexander F. Peliy ${ }^{2}$, Polina S. Semeshkina ${ }^{1}$, \\ Ekaterina S. Borodina ${ }^{3}$, Ameth Diop ${ }^{2}$ \\ ${ }^{1}$ Kaluga Research Institute of Agriculture, 249142, Kaluga region, village of Kaluga Experimental \\ Agricultural Station, Russian Federation \\ 2Peoples' Friendship University of Russia, 117198, Moscow, Russian Federation \\ ${ }^{3}$ RSAU - MTAA named after K.A. Timiryazev, 127550, Moscow, Russian Federation
}

\begin{abstract}
In the conditions placor soil Meshchovskiy Opole the Central economic region of the Nonchernozem zone of the Russian Federation on agro-gray forest middle loamy soils defined by the main species composition of segetal complex field agrophytocenoses in the structure of five fields grain and grain-grass crop rotation in the limit of syntaxon Stellarietea mediae R. Tx. et al. ex von Rochow 1951. The combinations of weed and field species specific to field crops are established and the influence of minimization of basic tillage is shown, including No-till, and applying calculated norms of mineral fertilizers (NPK) on the dynamics of the species composition and number of the main components of the segetal complex is shown. The original synanthropic plant communities on the fallow lands of Meshchovsky Opole develop from the segetal complex of previous agrophytocenoses. The core of the cenoflora is represented by 104 species of higher herbage plants from 29 families. Synanthropic communities have a low species saturation -8 species per $100 \mathrm{~m}^{2}$ and a projection coverage of $57.6 \%$. In acesite territories the advantage is given to the types of anemochory edificatory. Phytomass of secondary phytocenoses without comprehensive measures to improve their floristic composition cannot be used for bulk feed production
\end{abstract}

\section{Introduction}

Field community segetal species are formed in specific agro-climatic conditions and depending on between the cenofloras floristic regions, agricultural crops, structure of crop rotation, intensification of agricultural technology and level of environmental and economic development entity, developing floristically impoverished local segetal complexes, but with a relatively constant set of species, one of the regular causes of the declining productivity of arable land.

Modern adaptive landscape systems of agriculture are aimed at regulating the number of segmental price elements in agrophytocenoses at a level below their economic threshold of

\footnotetext{
*burlutskyvalery@gmail.com
} 
harmfulness [1-5]. The floral composition of pioneer communities developing on fallow lands is diverse and varies from the previous segetal complex, a set of crops on arable land, and the ecological and soil conditions of the area. The analysis of successional variability of naturally formed vegetation cover on a temporarily abandoned arable land removed from active agricultural turnover is of scientific and practical significance for assessing the economic potential and developing technologies for their targeted accelerated development [6-8].

\section{Materials and methods}

Research on the floristic composition of weed-field communities was conducted in 19992019 at the Kaluga research Institute of agricultural in biologized five-field crop rotation (total area $-4950 \mathrm{~m}^{2}$, area of 1 plot $-110 \mathrm{~m}^{2}$, repeatability - 3 times, location-tiered) with varying degrees of saturation of the structure with leguminous and leguminous perennial grasses: crop rotations without complete fallow - 30\% (Pisum sativum L. - Solanum tuberosum L. - Fagopyrum esculentum Moench - Vicia sativa L. + Avena sativa L. Triticum aestivum L. / X Triticosecale Witm. ex A. Gamus) and 40\% (Vicia faba L. - S. tuberosum L. - Hordeum vulgare L. + Trifolium pratense L.- T. pratense - T. aestivum), grain-grass $-60 \%$ (L. angustifolius $-T$. aestivum $+T$. pratense $-T$. pratense $-T$. pratense Triticosecale) on agro-gray forest middle loamy soils on placor.

Research on the floristic composition of the pioneer stages of synanthropic plant communities was conducted in 2006-2019 at the Kaluga research Institute in a field experiment to study the evolution of secondary phytocenoses and the development of alternative technologies for accelerated development of abandoned land on a plot of 110.0 hectares located on a smooth hillslope of the over-floodplain terrace of the South-Eastern exposure in the Oka - Vyssa rivers interfluve. Analysis (cenoflora) of abandoned lands by a set of plant species forming communities of any rank and any type of vegetation in 20092019 in the Peremyshlskiy, Sukhinicheskiy, Babyninskiy and Meshchovskiy districts of the Kaluga region.

\section{Results and discussion}

In agrophytocenoses, synanthropic field communities classified by J Braun-Blanquet [9, 10], derivatives were formed in the syntaxon limit Stellarietea mediae R. Tx. et al. ex von Rochow 1951. The core of the complex was determined by the types presented by us in descending order of their projective coverage:

- moderately (numerosae) - Achillea millefolium L., Capsella bursa-pastoris (L.) Medik, Centaurea cyanus L., Chenopodium album L., Cirsium arvense L., Convolvulus arvensis L., Echinochloa crusgalli (L.) Beauv., Elytrigia repens (L.) Nevski, Equisetum arvense L., Galeopsis tetrahit L., Galium aparine L., Matricaria chamomilla L., Polygonum aviculare L. s. 1., P. bistorta L., P. convolvulus L., Rumex acetosella L., Stelaria media L., Taraxacum officinalis Wigg., Thlaspi arvense L., Trifolium arvense L., Stachys arvensis L.;

- few (pauces) - Agrostis tenuis Sibth., Atriplex patula L., Cirsium setosum (Willd.) Bess., Consolida regalis S.P. Gray, Galeopsis speciosa Mill., Linaria vulgaris Mill., Matricaria perforate Merat., Menta arvensis L., Polygonum lapathifolium L., P. persicaria L., Raphanus raphanistrum L., Sonchus arvensis L., Spergula arvensis L.;

- rarely (rarae) - Barbarea vulgaris R. Br., Bunias orientalis L., Euphorbia helioscopia L., Fumaria officinalis L., Stachys palustris L.

Revealed increased phytocoenotic role rhizomatous segetal components in the period 2009 2019, relative to previous decades (figure 1). 


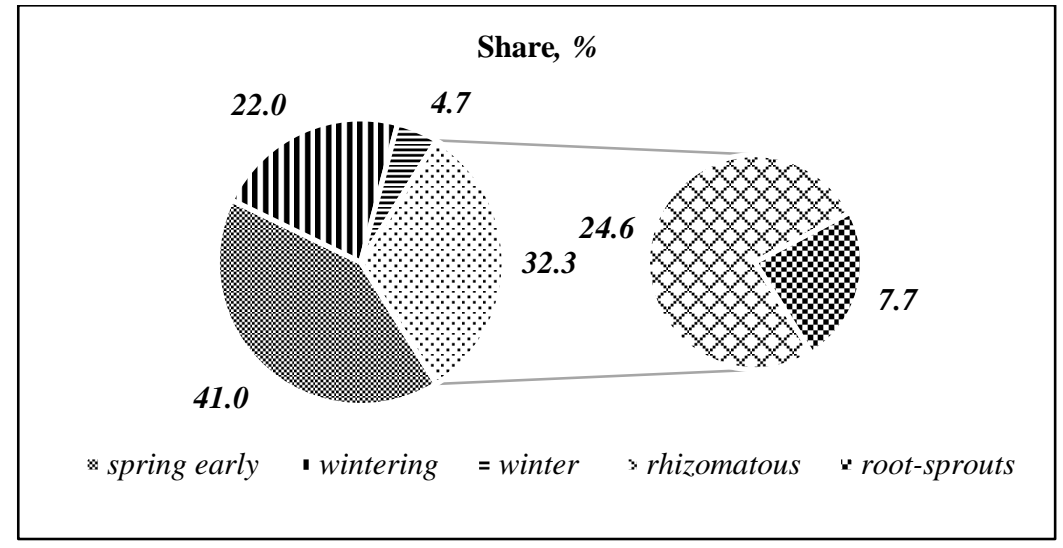

Fig. 1. Structure of a segmental complex

In agrophytocenoses, stable culturally specific combinations of segetal complex species were formed after the third rotation in the crop rotation (table 1).

Table 1. Main intra-field combinations of segetal species

\begin{tabular}{|c|c|}
\hline Agrophytocenos & Combination of species \\
\hline \multirow{2}{*}{$\begin{array}{l}\text { H. vulgare, } \\
\text { T. aestivum, } \\
\text { Triticosecale, } \\
\text { V. sativa }+ \text { A. sativa }\end{array}$} & $\begin{array}{l}\text { I - A. millefolium, E. repens, Eq. arvense, } \\
\text { C. cyanus, Ch. album, } C . \text { arvensis, } M . \text { arvensis, } \\
\text { P. aviculare, } P . \text { convolvulus, } S . \text { arvensis, } S . \text { media, }\end{array}$ \\
\hline & $\begin{array}{l}\text { II - A. tenuis, B. vulgaris, Eu. helioscopia, } \\
P . \text { persicaria, T. officinalis, Th. arvense }\end{array}$ \\
\hline \multirow{2}{*}{ F. esculentum } & $\begin{array}{c}\mathrm{I}-\text { - C. cyanus, Ch. album, } P . \text { aviculare, } P . \text { convolvulus, } S . \\
\text { arvensis, } S . \text { media, } T \text {. arvense }\end{array}$ \\
\hline & $\begin{array}{l}\text { II - A. millefolium, E. repens, Eq. arvense, } \\
\text { M. arvensis, } R \text {. acetosella }\end{array}$ \\
\hline \multirow{2}{*}{$\begin{array}{l}\text { L. angustifolius, } \\
\text { P. sativum, V. faba }\end{array}$} & I -C. setosum, R. acetosella, S. arvensis \\
\hline & $\begin{array}{c}\text { II - A. tenuis, B. vulgaris, Eq. arvense, E. repens, } \\
\text { Eu. helioscopia, M. arvensis, } P . \text { persicaria }\end{array}$ \\
\hline \multirow[b]{2}{*}{ T. pratense } & I -A. millefolium, E. repens, Eq. arvense \\
\hline & $\begin{array}{c}\text { II }-C . \text { arvensis, } P . \text { persicaria, } R . \text { acetosella, } S . \text { arvensis, } S . \\
\text { media, } T . \text { officinalis }\end{array}$ \\
\hline
\end{tabular}

Note: I - characteristic, II - accompanying

In the link of crop rotation legumes - winter cereals, the use of basic shallow tillage (disking-BDU-2.5) contributed to an increase in weed infestation of crops on average in one field by $52 \%$, and the technology (direct seeding) No-till (RAPID A600) - by 65\%, relative to the annual plow up (PLN-3-35) - 28 copies $/ \mathrm{m}^{2}$. The application of mineral fertilizers (NPK) in the norms calculated using the full balance method increased the participation of components of the segetal complex by $6 \ldots 15 \%$ in the structure of agrophytocenoses.

Communities of fallow period were assigned to syntaxons to the class Stellarietea mediae Tx. et al. ex von Rochow 1951, later ones belong to the class Artemisietea vulgaris Lohmeyer et al. ex von Rochow 1951. The syngenetic series was limited by pyrogenic influence. Derivatives were prone to frequent fluctuations. Cenoses had a low saturation -8 species per $100 \mathrm{~m}^{2}$, the projection coverage-57.6\% on average. The spectrum consisted of 104 species of higher plants of 29 families, the most frequent of which were: Achillea millefolium L., Agrostis capillaris L., Alchemilla vulgaris L., Apera spica-venti (L.) Beauv., Artemisia absinthium L., A. abrotanum L., A. vulgaris L., Barbarea vulgaria R. Br., Berteroa incata 
(L.) DC., Capsella bursa-pastoris (L.) Medik, Carex spp., Carum carvi L., Centaurea jacea L., Chenopodium album L., Convolvulus arvensis L., Cichorium intybus L., Cirsium setosum (Willd.) Bess., Dactylis glomerata L., Deschampsia caespitosa (L.) Beauv., Echinochloa crus-galli (L.) Beauv., Equisetum arvense L., Elytrigia repens (L.) Nevski, Erodium cicutarium (L.) L' Her., Erigeron canadensis L., Euphorbia virgata Waldst. et Kit., Galingosa parviflora Cav., Galeopsis tetrahit L., Glechoma hederacea L., Festuca spp., Hypericum perforatum L., Juncus spp., Leontodon autumnalis L., Leucanthemum vulgare Lam., Matricaria discoidea DC., Phleum pratense L., Plantago media L., P. major L., Poa annua L., P. pratensis L., P. trivialis L., Polygonum aviculare L. s. 1., Potentilla anserina L., Ranunculus acer L., R. repens L., Rumex acetosella L., R. confertus Willd., Sonchus arvensis L., Spergula arvensis L., Stellaria media (L.) Vill., S. graminea L., Tanacetum vulgare L., Taraxacum officinale Wigg., Thlaspi arvense L., Trifolium spp., Tussilago farfara L., Vicia spp., Viola arvensis Murr.

The community was presented agrobiological groups of grasses $(55 \%)$, cereals $(25 \%)$, legumes $(15 \%)$, spore $(10 \%)$ and sedge-juncaceae $(5 \%)$. Cenoses with adventive participation were more variable in productivity and quality of biomass, the yield was 1.5 times higher than that of native plants $[11,12]$. The number of species in communities was due to the diversity of the segetal complex, and its increase was due to the possibility and availability of immigration of diasporas. Species abundance was determined by the prevailing groups. Mutually complementary relationships appeared between cereals and legumes, herbs, and spores, sedge-juncaceae in other combinations - antagonistic (Table 2).

Table 2. Correlation coefficient $\left(\mathrm{r} \pm \mathrm{r}_{\mathrm{s}}\right)$ relationships of agrobiological groups

\begin{tabular}{|c|c|c|c|c|}
\hline Agrobiological group & Legumes & Motley grass & $\begin{array}{c}\text { Sedge- } \\
\text { juncaceae }\end{array}$ & Spore \\
\hline Cereal & $0.95 \pm 0.04$ & $-0.98 \pm 0.01$ & $-0.60 \pm 0.21$ & $-0.88 \pm 0.10$ \\
\hline Legumes & - & $-0.99 \pm 0.01$ & $-0.33 \pm 0.26$ & $-0.95 \pm 0.04$ \\
\hline Motley grass & & - & $0.40 \pm 0.24$ & $0.92 \pm 0.06$ \\
\hline Sedge-juncaceae & - & - & - & $0.32 \pm 0.29$ \\
\hline
\end{tabular}

In the motley grass group Compositae the proportion species was $20 \%$ and 5 advents (Erigeron annus (L.) Pers., E. canadensis L., Galingosa parviflora Cav., Matricaria discoidea DC., Solidago gigantea Ait.). Share of species Amaranthaceae, Chenopodiaceae Convolvulaceae, Fumariaceae, Hypericaceae, Onagraceae, Papaveraceae, Violaceae was low $-6,4 \%$ (Fig. 2).

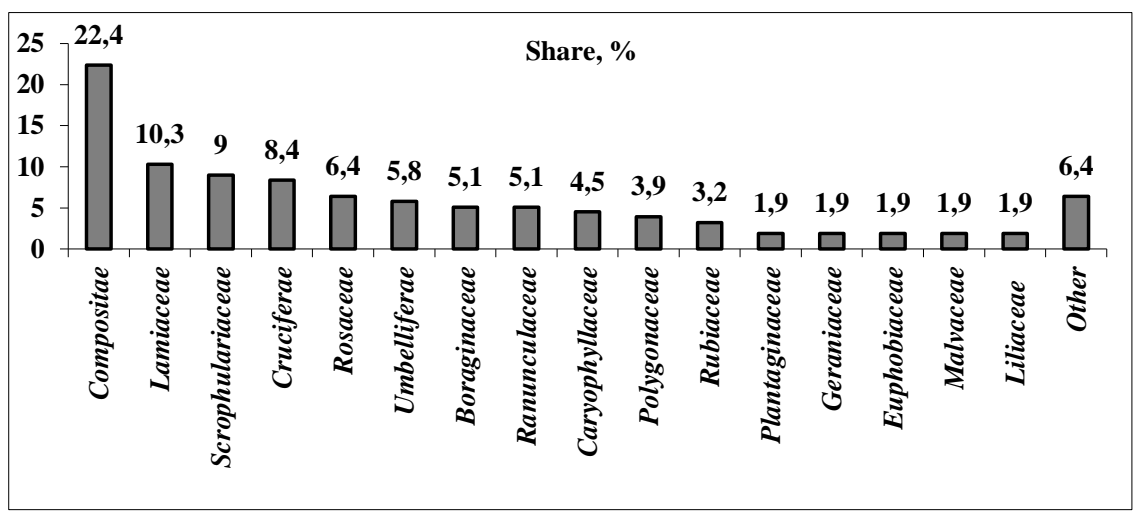

Fig. 2. Distribution of families in the motley grass group 
Communities in statu nascendi were subjected to anemochoric invasion of diasporas. Aggregations developed that correlated with the structure of bordering communities. The degree of abundance on the Drode scale for Salix spp. was - $\mathrm{Sol}_{\mathrm{gr}} / \mathrm{Sp}-\mathrm{Cop}_{1}$, Betula spp. Sol $_{\mathrm{gr}}-\mathrm{Sp} / \mathrm{Cop}_{1}$, Populus tremula L. - Un-Sol/Sp, Pinus sylvestris L. - Un $\mathrm{Ur}_{\mathrm{gr}} / \mathrm{Sol}_{\mathrm{gr}}$, and (neophyte) Acer nedugo L. - Un/Un-Sol. Advantages in ecesis were anemochora species edificators Salicaceae, Betulaceae, Pinaceae.

\section{Conclusion}

The main floral composition of the segetal complex of field agrophytocenoses in the syntaxon limit in the conditions of Meshchovskiy Opole was determined Stellarietea mediae R. Tx. et al. ex von Rochow 1951. Cultural-specific combinations of weed-field vegetation species have been established. Minimization of the main tillage and introduction of calculated norms of mineral fertilizers contributes to an increase in the degree of contamination of crops by 52 ... $65 \%$ in biologized farming systems. Characteristics of secondary phytocenoses indicate that without a complex of agrotechnological techniques to improve their floral composition, phytomass cannot be important in the production of bulky feed. Communities are formed by 104 species of higher herbage plants from 29 families have low species saturation and low projective coverage and develop from the segmental complex of previous agrophytocenoses. In ecessis anemochores edificators have an advantage.

\section{References}

1. A. Kashtanov, O. Sizov, E. agr. in Rus., 11, 174 (2008)

2. N. Semenov, N. Muromtsev, A. Snitko, For. prod., 3, 3 (2016)

3. J. Alix-Garcia, Land Use Pol., 59, 284 (2016)

4. A. Prishchepov, D. Müller, M. Dubinin, Land Use Pol., 30, 4, 873 (2013)

5. Y. Helin, D. Juan, J. RUDN: Ecol. \& 1. s. 3, 17 (2014)

6. V. Burlutskiy, V. Mazurov, P. Semeshkina et all, Bul. Rus. agr. scien., 3, 18 (2019)

7. M. Makarova, M. Redina, A. Popkova, J. RUDN, Ecol. \& 1. s., 25, 1, 7 (2017)

8. G. Sigora, L. Nichkova, T. Khomenko, J. RUDN, Ecol. \& 1. s., 25, 1, 88 (2017)

9. J. Braun-Blanquet, Pflanzensociologie (Wien, 1964)

10. N. Ermakov, B. Mirkin, L. Naumova, The current state of the vegetation (Ufa, Gilem, 2012)

11. V. Burlutskiy, V. Mazurov, I. Osokin et all, J. RUDN, Agr. \& anim. husb.,14, 2, 114 (2019)

12. E. Garnier, M.-L. Navas, K. Grigulis, Plant Functional Diversity: Organism traits, community structure, and ecosystem properties (Oxford, Oxf. Un. Pr., 2016) 